\title{
Enhanced lipid peroxidation and lysosomal enzyme activity in the lungs of rats with prolonged pulmonary deposition of crocidolite asbestos
}

\author{
JOLANTA JAJTE, ${ }^{1}$ IWONA LAO ${ }^{2}$ JUSTYNA M WIŚNIEWSKA-KNYPL ${ }^{1}$ \\ From the Departments of Biochemistry ${ }^{1}$ and of Pathomorphology, ${ }^{2}$ Professor $J$ Nofer Institute of Occupational \\ Medicine, 90-950 Lodz, Poland
}

ABSTRACT The interaction of UICC crocidolite asbestos with biological membranes in vivo was studied in rats after a single intratracheal dose of a suspension of $20 \mathrm{mg}$ of fibres per rat. Development of lung fibrosis (increased level of hydroxyproline, a collagen index together with corresponding pathomorphological alteration) confirmed the penetration of crocidolite fibres into the lungs in the course of seven months exposure. The pulmonary deposition of crocidolite affected the lysosomal membranes of lung cells as manifested by (1) enhanced lipid peroxidation with (2) stimulation (release) of activity of $\beta$-glucuronidase and cathepsin D. Enhanced lipid peroxidation and activity of $\beta$-glucuronidase may contribute to the delayed, carcinogenic effects of crocidolite asbestos.

The health hazard of exposure to asbestos in industry arises from its fibrogenic and carcinogenic activity. ${ }^{1}$ The basic mechanism of the diverse biochemical events caused by asbestos at the molecular and subcellular level-that is, fibrosis, cytotoxicity, and carcinogenesis ${ }^{2}{ }^{3}$-may be linked with the interaction of asbestos or its organic components with cellular and subcellular membranes, or both.

A selective release of lysosomal enzymes ${ }^{4}$ with the stimulation of lipid peroxidation ${ }^{35}$ has been found after the addition of asbestos to cell culture which correlates with the alteration of permeability of cellular membranes and cell death. ${ }^{67}$ In vitro experiments with red blood cells ${ }^{5}$ and microsomes isolated from liver and lungs ${ }^{8}$ showed that asbestos stimulates lipid peroxidation. Since the rate of lipid peroxidation was dependent on the amount of asbestos bound to microsomes ${ }^{8}$ it is highly probable that the long term intimate contact of asbestos with biological membrane permits the reaction of short lived radicals with unsaturated fatty acids thus affecting the integrity and selective physicochemical characteristics of the membrane. It is suggested that free oxygen radicals may be linked with carcinogenesis: malondialdehyde, a prod-

Accepted 13 May 1986 uct of lipid peroxidation, has been found to be mutagenic and carcinogenic. ${ }^{9}$

The asbestos provoked peroxidative attack may possibly lead to an alteration in the fluidity of biomembranes thus affecting the activity of some membrane bound enzymes, especially in lysosomes, a target cellular subfraction for asbestos fibres. The release of lysosomal enzymes from pulmonary macrophages and inflammatory cells may influence the cleavage of endogenous components (protein and nucleic acids) and conjugated derivatives of xenobiotics (polycyclic aromatic hydrocarbons, adsorbed on asbestos and readily transferred to membranes). ${ }^{10}$

This investigation was undertaken to determine whether, in vivo, a prolonged pulmonary deposit of crocidolite UICC standard asbestos affects the activity of lysosomal enzymes and lipid peroxidation in this critical organ.

\section{Materials and methods}

ANIMALS AND TREATMENT

Experiments were carried out with male Wistar rats (200-250 g) fed with a laboratory diet-Murigran (Bioveterinary Industries, Gorzów Wielkopolski, Poland) and tap water as wanted.

The exposure of rats to crocidolite, the UICC reference asbestos standard (cf Timbrell ${ }^{11}$ ), was achieved 
under anaesthesia with a drop of $4 \%$ xsylocain sprinkled directly on the glottis, by a single intratracheal instillation of a suspension of $20 \mathrm{mg}$ of asbestos fibres in $0.2 \mathrm{ml}$ of physiological saline per animal. Control animals received only saline. The animals were killed at one, three, and seven months after dosing and their lungs were used for the tests.

\section{BIOCHEMICAL ASSA YS}

Rats were killed by decapitation under light ether anaesthesia and the lungs were excised, washed with physiological saline, blotted on a filter paper, and immediately processed.

Fresh lungs were weighed directly and dry weight was determined after an initial five hour desiccation at $50^{\circ} \mathrm{C}$ and then, to a constant weight, over phosphorus pentoxide.

Hydroxyproline in the collagen fraction of dry lungs was determined colorimetrically at $550 \mathrm{~nm}$, after extraction, according to Stegemann and Stalder, ${ }^{12}$ and converted to collagen by using a factor of $7 \cdot 46$ according to Schaub. ${ }^{13}$

For the isolation of the lysosomal fraction (cf Sawant et $\left.\mathrm{al}^{14}\right), 10 \%(\mathrm{w} / \mathrm{v})$ homogenate of fresh lungs in $0.25 \mathrm{M}$ sucrose $-0.01 \mathrm{M}$ Tris- $\mathrm{HCl}, \mathrm{pH} 7.4$ obtained with a teflon glass Potter-Elvehjem homogeniser and squeezed through a bolting cloth (pores of $200 \mu$ in diameter) was successively centrifuged at $4^{\circ} \mathrm{C}$ at $900 \mathrm{~g}$ for 10 minutes, $7000 \mathrm{~g}$ for 15 minutes, and $20400 \mathrm{~g}$ for 35 minutes to sediment nuclei, mitochondria, and lysosomes, respectively. After washing with $1 \cdot 15 \%$ $\mathrm{KCl}$ and recentrifugation at $20400 \mathrm{~g}$ for 35 minutes, the lysosomal fraction was suspended by rehomogenisation in $1.15 \% \mathrm{KCl}$. Protein was determined according to Lowry et al. ${ }^{15}$

Activity of $\beta$-glucuronidase (EC 3.2.1.31) was assayed by the method of Nimmo-Smith ${ }^{16}$ with p-nitrophenol glucuronide as substrate; the p-nitrophenol formed was determined colorimetrically at $400 \mathrm{~nm}$.
Activity of cathepsin D (EC 3.4.23.5) was assayed by the method of Anson ${ }^{17}$ with denaturated haemoglobin as substrate; acid soluble products of hydrolysis of the protein were determined with Folin phenol reagent. ${ }^{15}$

Lipid peroxidation in the homogenates and lysosomal membranes was evaluated on the basis of the detection of thiobarbituric acid reactive substances according to Mihara et al. ${ }^{18}$ An extinction coefficient of $156000 / \mathrm{M} / \mathrm{cm}$ according to Wills ${ }^{19}$ was used for malondialdehyde formation.

Results were statistically evaluated using Student's $t$ test.

\section{PATHOMOR PHOLOGICAL EXAMINATION OF THE LUNGS}

Lungs were fixed in situ at full inflation by the infusion of $10 \%$ neutral buffered formalin through the larynx and trachea. After ligation of the trachea, all the chest organs were excised and placed in $10 \%$ buffered formalin solution for continued fixation. The sections were gradually dehydrated in isopropanol (50-96\%), cleared in xylene, and impregnated with paraffin. Haematoxylin and eosin stained paraffin sections were examined with a light microscope.

\section{Results}

Table 1 gives the data showing the effects of long term action of crocidolite fibres on the lungs. After three months the dry weight of the lungs of the experimental animals increased due to the development of fibrosis as inferred from the increase in their collagen content. Continued exposure to crocidolite for the next four months (seven months from the instillation of asbestos) resulted in a tendency for the fibrotic reaction in the lungs to diminish.

The biochemical findings were confirmed by the pathomorphological examination of the lungs (cf figs 1-4). Figure 1 shows a fragment of lung tissue from a

Table 1 Course of the increase in weight of the lungs and pulmonary content of collagen and lysosomal proteins in rats after intratracheal instillation of crocidolite UICC asbestos

\begin{tabular}{|c|c|c|c|c|c|}
\hline Groups & $\begin{array}{l}\text { Time after } \\
\text { asbestos } \\
\text { instillation } \\
\text { (months) }\end{array}$ & $\begin{array}{l}\text { Body weight } \\
(g)\end{array}$ & $\begin{array}{l}\text { Lungs, } \\
\text { dry weight, } \\
(g)\end{array}$ & $\begin{array}{l}\text { Collagent } \\
\text { (mg per lungs } \\
\text { dry weight) }\end{array}$ & $\begin{array}{l}\text { Lysosomal proteins } \\
\text { (mg per lungs } \\
\text { fresh weight) }\end{array}$ \\
\hline $\begin{array}{l}\text { Control }(0.9 \% \mathrm{NaCl}) \\
\text { Crocidolite UICC } \\
\text { Control }(0.9 \% \mathrm{NaCl}) \\
\text { Crocidolite UICC } \\
\text { Control }(0.9 \% \mathrm{NaCl}) \\
\text { Crocidolite UICC }\end{array}$ & $\begin{array}{l}1 \\
3 \\
7\end{array}$ & $\begin{array}{l}259 \pm 6 \\
270 \pm 9 \\
324 \pm 9 \\
342 \pm 15 \\
351 \pm 13 \\
341 \pm 6\end{array}$ & $\begin{array}{l}0.26 \pm 0.02 \\
0.39 \pm 0.09 \\
0.26 \pm 0.01 \\
0.46 \pm 0.04^{* *} \\
0.32 \pm 0.01 \\
0.35 \pm 0.01^{*}\end{array}$ & $\begin{array}{l}28.87 \pm 1.30 \\
62.29 \pm 3.78^{* *} \\
30.81 \pm 2.27 \\
75.87 \pm 4.45^{* *} \\
38.64 \pm 1.75 \\
52.22 \pm 1.36^{* *}\end{array}$ & $\begin{array}{c}6.23 \pm 0.30 \\
11.56 \pm 0.71^{* *} \\
8.08 \pm 0.38 \\
12.36 \pm 0.79^{* *} \\
8.27 \pm 0.39 \\
13.95 \pm 0.84^{* *}\end{array}$ \\
\hline
\end{tabular}

*,**Significantly different from concurrent controls at $p=0.05$ and 0.001 , respectively.

+Hydroxyproline was converted to collagen using a factor of 7.46 according to Schaub. ${ }^{i 3}$

+ Determined according to Lowry et al. ${ }^{15}$

Results are the mean \pm SE for 16 rats. 
Fig 1 Lung of control rat, three months after intratracheal instillation of $0.2 \mathrm{ml}$ physiological saline. Normal picture of pulmonary parenchyma with regular aerial space of alveoli and smooth contour of bronchi is seen. ( $H$ and $E, \times 40$.)

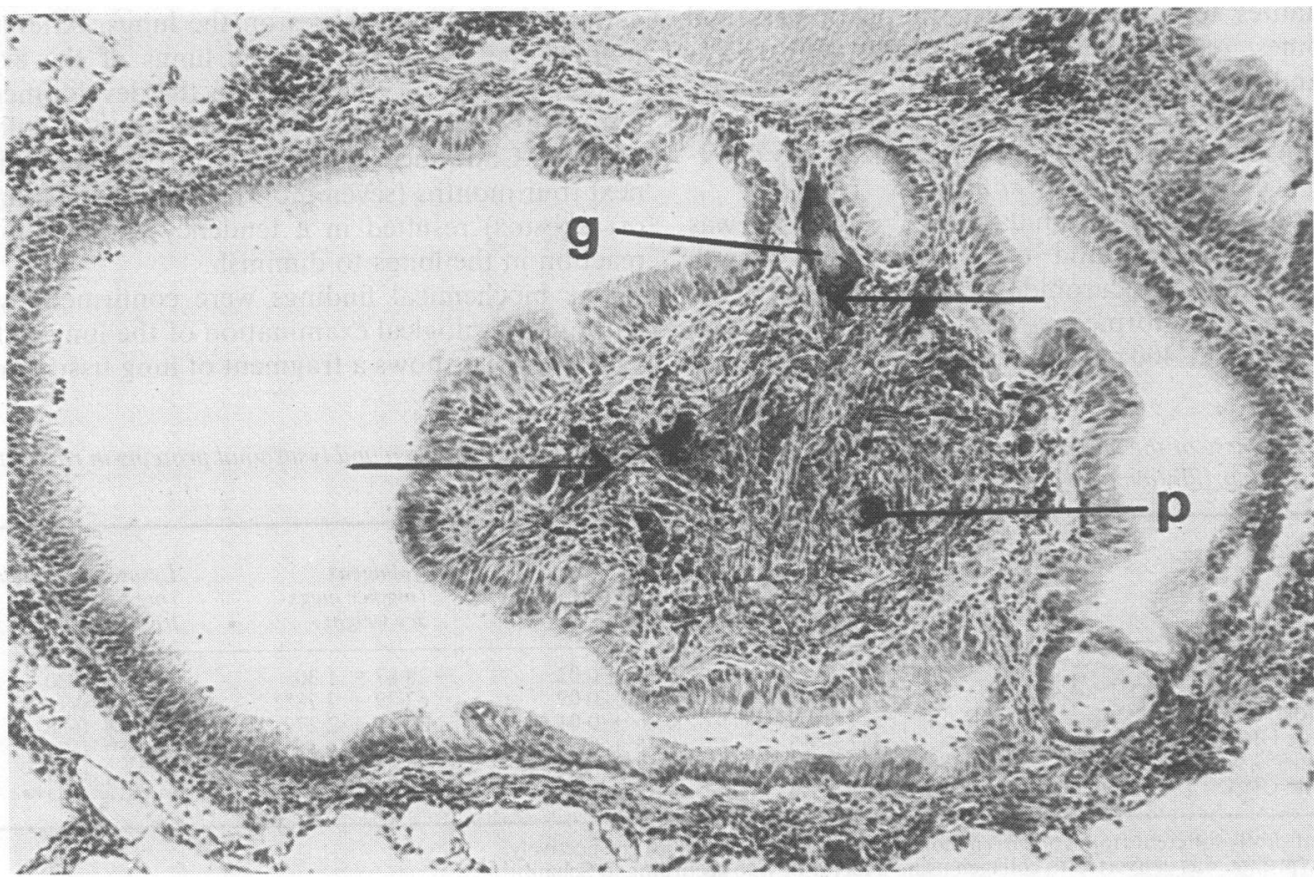

Fig 2 Lung of rat, three months after intratracheal instillation of suspension of $20 \mathrm{mg}$ crocidolite UICC asbestos. Granuloma protruding into the lumen of bronchi with numerous crocidolite fibres (arrows), phagocytes ( $p$ ), and a giant cell $(g)$ are seen. ( $H$ and $E, \times 95$.) 


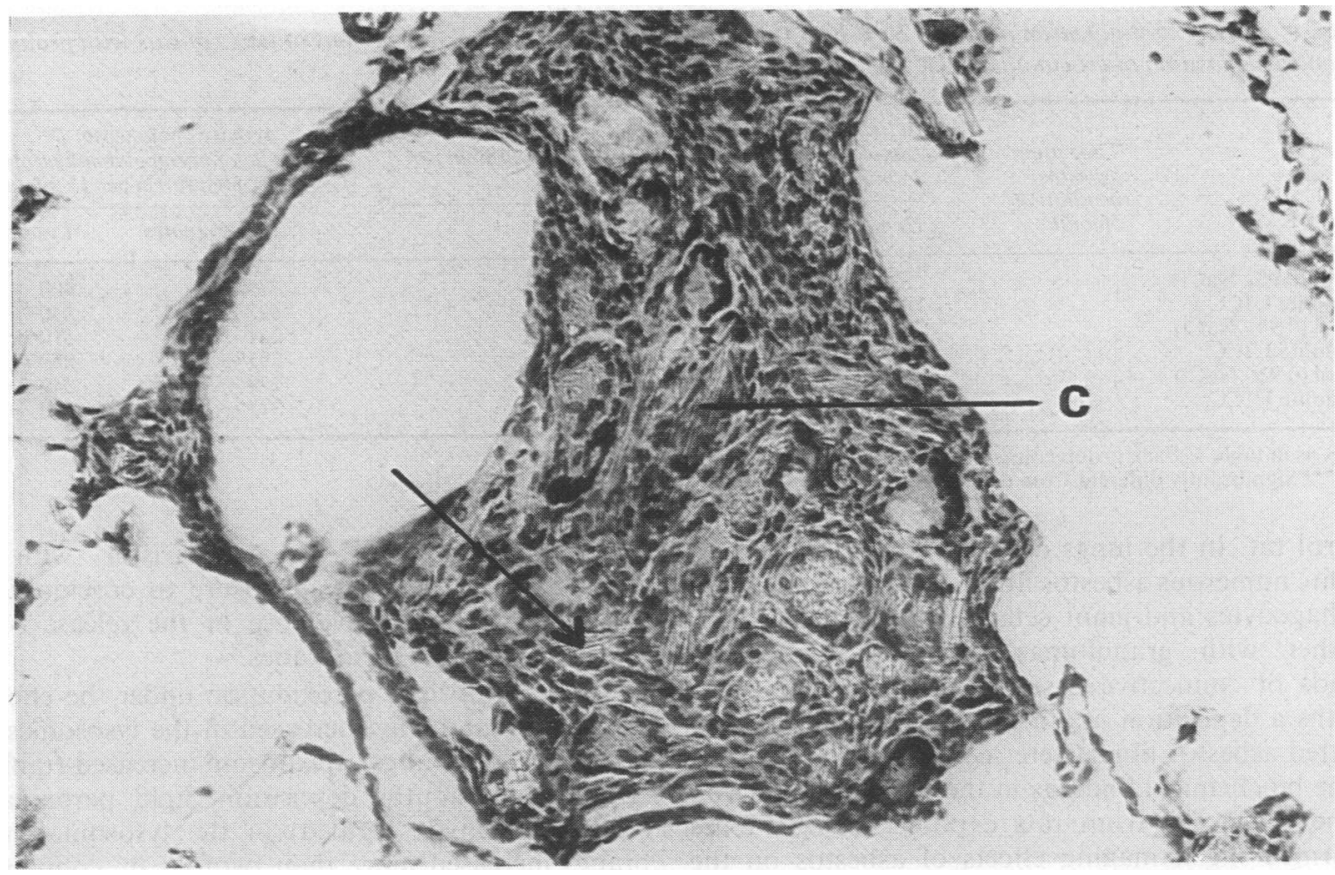

Fig 3 Lung of rat, seven months after intratracheal instillation of suspension of $20 \mathrm{mg}$ crocidolite UICC asbestos. Mature, well organised granuloma containing asbestos fibres (arrow) and strands of connective tissue (c) are seen. ( $H$ and $E, \times 95$.)

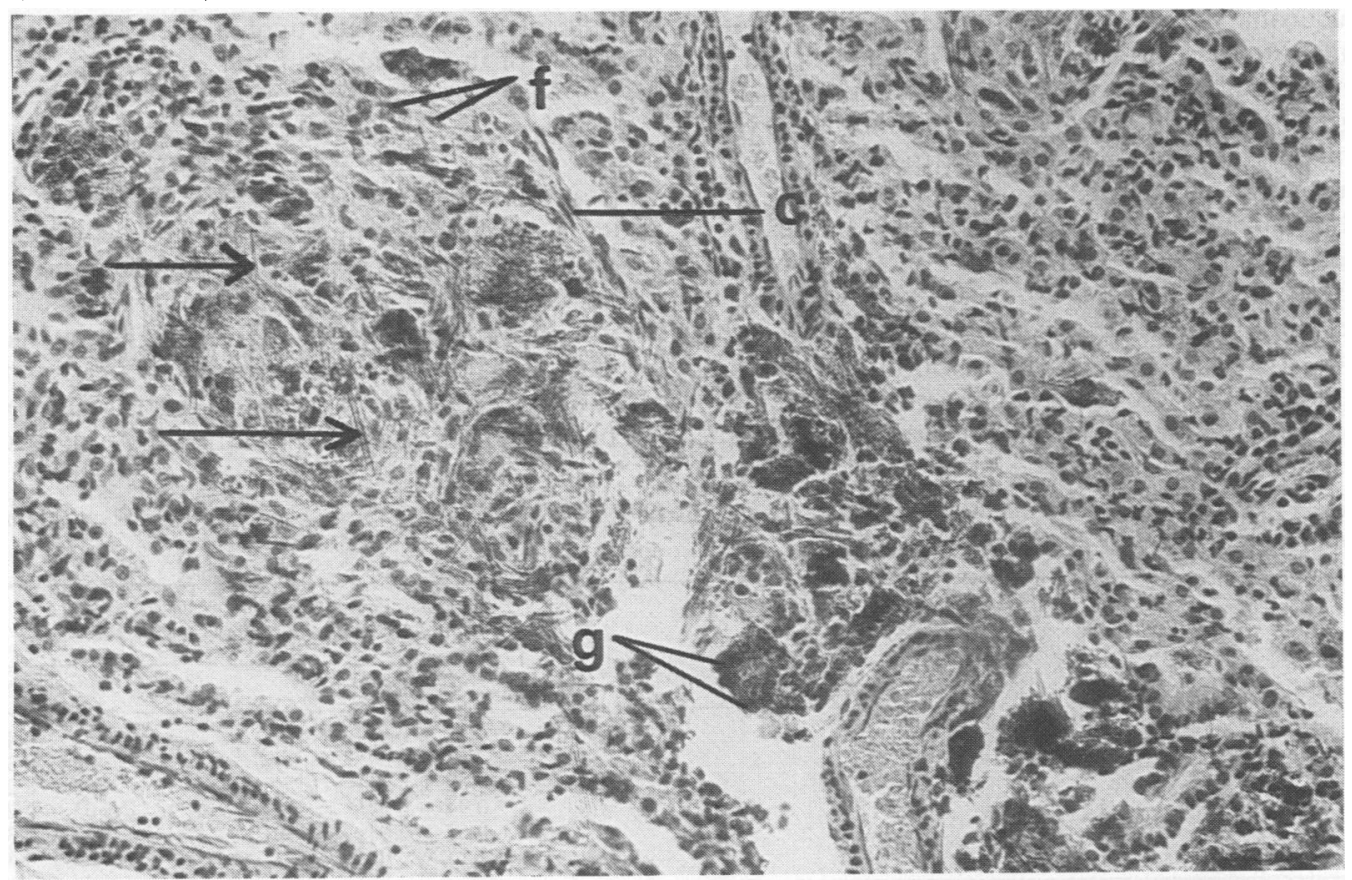

Fig 4 Lung of rat, seven months after intratracheal instillation of suspension of $20 \mathrm{mg}$ crocidolite UICC asbestos. A fragment of atelectotic pulmonary lobe. Typical, undermarcated granuloma in vicinity of blood vessels with asbestos fibres (arrows) and giant cells $(\mathrm{g})$. At periphery of granuloma, strands of connective tissue $(c)$ and fibroblasts $(f)$ are seen. (H and $E, \times 237$.) 
Table 2 Activity of $\beta$-glucuronidase and cathepsin $D$ in homogenates and lysosomal fractions of lungs of rats with prolonged pulmonary deposition of crocidolite UICC asbestos

\begin{tabular}{|c|c|c|c|c|c|}
\hline \multirow[b]{2}{*}{ Groups } & \multirow{2}{*}{$\begin{array}{l}\text { Time after } \\
\text { asbestos } \\
\text { instillation } \\
\text { (months) }\end{array}$} & \multicolumn{2}{|c|}{$\begin{array}{l}\text { Activity of } \beta \text {-glucuronidase } \\
\text { (nmoles of p-nitrophenol formed per } \mathrm{mg} \text { protein per } \\
\text { I5 minutes) }\end{array}$} & \multicolumn{2}{|c|}{$\begin{array}{l}\text { Activity of cathepsin } D \\
\text { ( } \mu \text { g of haemoglobin hydrolysed } \\
\text { per mg protein per } 15 \text { minutes) }\end{array}$} \\
\hline & & Homogenates & Lysosomes & Homogenates & Lysosomes \\
\hline $\begin{array}{l}\text { Control }(0.9 \% \mathrm{NaCl}) \\
\text { Crocidolite UICC } \\
\text { Control }(0.9 \% \mathrm{NaCl}) \\
\text { Crocidolite UICC } \\
\text { Control }(0.9 \% \mathrm{NaCl}) \\
\text { Crocidolite UICC }\end{array}$ & $\begin{array}{l}1 \\
3 \\
7\end{array}$ & $\begin{array}{l}52 \pm 5 \\
180 \pm 20^{* * *} \\
68 \pm 3 \\
105 \pm 8^{* * *} \\
66 \pm 12 \\
91 \pm 11\end{array}$ & $\begin{array}{l}60 \pm 10 \\
110 \pm 10^{* *} \\
70 \pm 10 \\
100 \pm 10^{*} \\
70 \pm 10 \\
90 \pm 10\end{array}$ & $\begin{array}{l}273 \pm 26 \\
623 \pm 41^{* * *} \\
261 \pm 18 \\
391 \pm 23^{* *} \\
279 \pm 16 \\
372 \pm 36^{*}\end{array}$ & $\begin{array}{l}400 \pm 50 \\
550 \pm 50^{*} \\
510 \pm 90 \\
850 \pm 100^{*} \\
340 \pm 40 \\
480 \pm 40^{*}\end{array}$ \\
\hline
\end{tabular}

Details as in table 1. Each group consisted of 10 rats.

${ }^{*},{ }^{*},{ }^{* *}$ Significantly different from concurrent controls at $\mathrm{p}=0.05,0.01$, and 0.001, respectively.

control rat. In the lungs of the rats exposed to crocidolite numerous asbestos fibres, locked on the inside of phagocytes and giant cells, were observed (fig 2) together with granulomas, asbestos fibres, and strands of connective tissue (figs 3-4). After seven months a deposition in atalectotic regions and accumulated asbestos fibres were seen (fig 4).

The biochemical findings in the lysosomal fraction of the lung cells from rats exposed to crocidolite confirmed the damaging effects of asbestos on the membranes; as exposure continued, the content of lysosomal protein in the lung cells increased (table 1) with a concomitant increase of activity of $\beta$-glucuronidase and cathepsin D (table 2). An almost parallel increase in the activity of the enzymes in the lysosomal subfraction and whole homogenates may suggest a crocidolite provoked release of the enzymes from the lysosomal membrane rather than a mere enhancement of their activities.

The highest increase in the activity of $\beta$-glucuronidase and cathepsin $D$ in the lysosomes and whole homogenates was observed between one to three months after the asbestos instillation and this tended to diminish after seven months deposition, although the activity was still greater than the control value. The higher activity of lysosomal enzymes in the whole homogenates by comparison with the $\stackrel{+}{+}$ lysosomal fraction after exposure to crocidolite for one month may be evidence of the release of the $\stackrel{\circ}{\circ}$ enzymes from the membranes.

The level of lipid peroxidation under the effect of $\stackrel{?}{\rightarrow}$ crocidolite gradually increased in the lysosomes and 3 homogenate of lungs as exposure increased (table 3 ). After seven months deposition, lipid peroxidation (malondialdehyde formed) in the lysosomal membranes increased more than twofold by comparison with the non-exposed control. In the lung homogenate the level of lipid peroxidation per whole protein basis, although lower than in the lysosomes, was still significantly enhanced under the long lasting influence of the crocidolite fibres.

\section{Discussion}

The present investigation found that UICC crocidolite asbestos administered to rats intratracheally in a single dose of $20 \mathrm{mg}$ provoked, during the course of seven months, specific pathomorphological and biochemical alterations in the lungs. These changes 0 included the development of fibrosis (cf figs 1-4, table 3 . 1) and an increase in the content of lysosomal protein, $\delta$ a concomitant increase in the activity of the lysosomal

Table 3 Lipid peroxidation in homogenates and lysosomal fractions of lungs of rats with prolonged pulmonary deposition of crocidolite UICC asbestos

\begin{tabular}{|c|c|c|c|}
\hline \multirow[b]{2}{*}{ Groups } & \multirow{2}{*}{$\begin{array}{l}\text { Time after ashestos } \\
\text { instillation (months) }\end{array}$} & \multicolumn{2}{|c|}{$\begin{array}{l}\text { Lipid peroxidation } \\
\text { (nmoles of malondialdehyde per } m g \text { protein) }\end{array}$} \\
\hline & & Homogenates & Lysosomes \\
\hline $\begin{array}{l}\text { Control }(0.9 \% \mathrm{NaCl}) \\
\text { Crocidolite UICC } \\
\text { Control }(0.9 \% \mathrm{NaCl}) \\
\text { Crocidolite UICC } \\
\text { Control }(0.9 \% \mathrm{NaCl}) \\
\text { Crocidolite UICC }\end{array}$ & $\begin{array}{l}1 \\
3 \\
7\end{array}$ & $\begin{array}{l}0.77 \pm 0.05 \\
1.01 \pm 0.07^{* *} \\
0.68 \pm 0.01 \\
0.94 \pm 0.07^{* *} \\
0.63 \pm 0.07 \\
1.17 \pm 0.08^{* * *}\end{array}$ & $\begin{array}{l}3.44 \pm 0.42 \\
3.73 \pm 0.34 \\
4.03 \pm 0.24 \\
5.03 \pm 0.24^{*} \\
3.06 \pm 0.30 \\
7.53 \pm 0.38^{* * *}\end{array}$ \\
\hline \multicolumn{4}{|c|}{ 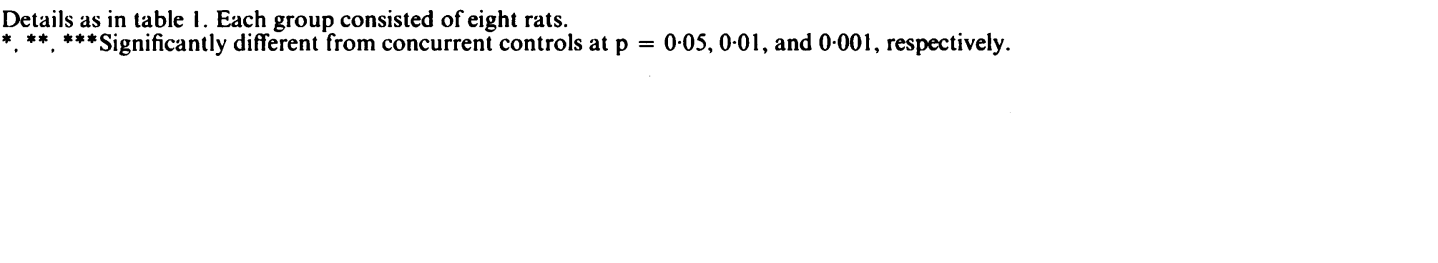 } \\
\hline
\end{tabular}


enzymes $\beta$-glucuronidase and cathepsin D (cf table 2), and enhancement of lipid peroxidation (cf table 3 ).

The results of this in vivo exposure of rats to crocidolite via the tracheobronchial tract have confirmed previously reported in vitro effects of asbestos fibres on lipid peroxidation in red blood cells, ${ }^{5}$ cultured tracheal epithelial cells, ${ }^{3}$ and microsomal membranes of lungs and liver ${ }^{8}$ and on the activity of lysosomal enzymes in cultured macrophages ${ }^{4}$ and pulmonary lavage. $^{2}$

The derangement of the integrity of biomembranes through the release of hydrolytic lysosomal enzymes and the stimulation of lipid peroxidation may be of importance for the delayed biological consequences of exposure to asbestos fibres. ${ }^{23}$ Stimulation of the activity of cathepsin D may contribute to the degradation of protein and probably collagen also, leading to a fibrotic reaction in the lung which diminishes in the course of prolonged exposure (cf tables 1 and 2). Asbestos mediated stimulation of the activity of $\beta$-glucuronidase may be linked with the carcinogenic potential of the fibres owing to the capability of $\beta$-glucuronidase to hydrolyse (reactivate) the inert, transport form of aromatic hydrocarbon glucuronide conjugates to their active derivatives. ${ }^{20}$ In vitro experiments have shown an increased transfer of aromatic hydrocarbons to microsomal membranes when adsorbed to asbestos, ${ }^{10}$ resulting in an increase in the activity of aromatic hydrocarbon hydroxylases ${ }^{3}$ via cytochrome $\mathrm{P}-448$ induction and, in effect, increased formation of ultimate carcinogens. Asbestos fibres might thus serve as a physical carrier mediating the transfer of carcinogens into the target tissue. This assumption may be supported by epidemiological evidence indicating that asbestos is cocarcinogenic - that is, a promoter-with cigarette smoke, generally known to contain volatile tar compounds. ${ }^{3}$

Brown et al on the basis of direct determinations suggest that asbestos can mediate two phenomena ${ }^{21}$ : (1) the increased uptake of xenobiotics, aromatic hydrocarbons, and (2) the inhibition of the accumulation of glucuronides, conjugated derivatives of hydrocarbons. These phenomena may lead to the predominance of the processes of metabolic bioactivation of hydrocarbons and their binding to DNA over their detoxication. The stimulation of the activity of $\beta$-glucuronidase in vivo by prolonged deposition of crocidolite, as shown in the present paper (cf table 2) reinforces the second assumption of Brown et al. $^{21}$

The cytotoxic and carcinogenic effects of crocidolite may also result from enhanced lipid peroxidation in biological membranes ${ }^{7819}$ as confirmed in vivo in lysosomes from lungs with prolonged asbestos deposition (table 3). The enhanced formation of malondialdehyde, a product of lipid peroxidation with mutagenic and carcinogenic properties ${ }^{922}$ most probably aggravates the pathological sequelae of exposure to asbestos. Iron, present in the structure of crocidolite fibres, is thought to be responsible for catalysing the peroxidation in a non-enzymatic way. ${ }^{8}$ As the chemically initiated ( $\mathrm{Fe}^{2+}$ and ascorbate) lipid peroxidation of polyunsaturated fatty acids is able to mediate the oxidation of benz(a)pyrene to epoxide derivatives, ${ }^{22}$ it is possible that a similar process mediated by the $\mathrm{Fe}^{2+}$ in crocidolite may play a part in the activation of precarcinogens and finally in carcinogenesis.

This study was carried out under the Programme of Evaluation of Biological Effects and Exposure to Industrial Dusts, CI.01.U.02.07 for the Central Institute of Labour Protection. We are grateful to Dr V Timbrell of the MRC Pneumoconiosis Research Unit, Llandough Hospital, Penarth, UK, for making available crocidolite UICC asbestos and to $\mathrm{Dr} T$ Wronska-Nofer of the Institute for Helpful Discussion. We thank Mrs Helena Płatak for skilled technical help and Mrs Zofia Rudnicka for typing.

\section{References}

1 Kannerstein M, Churg J, McCaughey WTE, Selikoff IJ. Pathogenic effects of asbestos. Arch Pathol Lab Med 1977;101:623-8.

2 Rahman G, Das B, Viswanathan PN. Biochemical mechanisms in asbestos. Environ Health Perspect 1983;51:299-303.

3 Mossman B, Light W, Wei E. Asbestos: mechanism of toxicity and carcinogenicity in the respiratory tract. Ann Rev Pharmacol Toxicol 1983;2:595-615.

4 Davies P, Allison AC, Ackerman J, Butterfield A, Williams S. Asbestos induced selective release of lysosomal enzymes from mononuclear phagocytes. Nature 1974;251:423-5.

5 Gabor S, Anca Z. Effects of asbestos on lipid peroxidation in the red cells. Br J Ind Med 1975;32:39-41.

6 Davies $R$. The effect of dust on enzyme release from macrophages. In: Brown RC, Chamberlain M, Davies R, Gormley IP, eds. The in vitro effects of mineral dusts. London: Academic Press, 1980:67-74.

7 Wills ED, Wilkinson AE. Release of enzymes from lysosomes by irradiation and the relation of lipid peroxide formation to enzyme release. Biochem $J$ 1966;99:657-66.

8 Gulumian M, Sardianos F, Kilroe-Smith T, Ockerse G. Lipid peroxidation in microsomes induced by crocidolite fibres. Chem Biol Interact 1983;44:111-8.

9 Yau TM. Mutagenicity and cytotoxicity of malonaldehyde in mammalian cells. Mechanism Ageing Development 1979;11:137-44.

10 Lakowicz JR, Bevan DR. Benzo(a)pyrene uptake into rat liver microsomes: effects of adsorption of benzo(a)pyrene to asbestos and non-fibrous mineral particulates. Chem Biol Interact 1980;29:129-38.

11 Timbrell V. Uses of the UICC samples. In: Wagner JC, ed. Biological effects of mineral fibres. Vol 1. Lyon: International Agency for Research on Cancer, 1980:127-41. (IARC sci publ No 30.)

12 Stegemann H, Stalder K. Determination of hydroxyproline. Chim Acta 1967;18:267-73. 
13 Schaub MC. Qualitative and quantitative changes of collagen in parenchymatous organ of the rat during ageing. Gerontologia 1963;8:114-22.

14 Sawant PL, Shibko S, Kumta US, Tappel AL. Isolation of rat liver lysosomes and their general properties. Bioch Biophys Acta 1964;85:82-92.

15 Lowry AH, Rosebrough NJ, Farr AL, Randall RJ. Protein measurement with the Folin phenol reagent. J Biol Chem 1951;193:265-75.

16 Nimmo-Smith RH. p-Nitrophenyl beta-glucuronide as a substrate for beta-glucuronidase. Biochem Biophys Acta 1961;50:166-9.

17 Anson ML. Proteolytic enzymes: cathepsin. In: Sumner JB, Somers RF, eds. Chemistry and methods of enzymes. New York: Academic Press Inc, 1947:192-3.
Jajte, Lao, Wiśniewska-Knypl $\stackrel{\frac{0}{c}}{\bar{c}}$

18 Mihara M, Uchiyama M, Fukuzawa K. Thiobarbituric acid

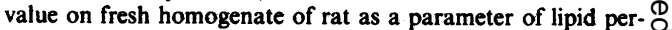
oxidation in aging, $\mathrm{CCl}_{4}$ intoxication and vitamin $\mathrm{E}$ deficiency. Biochem Med 1980;23:302-11.

19 Wills ED. Mechanism of lipid peroxide formation in animal tissues. Biochem $J$ 1966;99:667-76.

20 Kinoshita N, Gelboin HV. Beta-glucuronidase catalysed hydro- $\bar{\sigma}$ lysis of benzo(a)pyrene-3-glucuronide and binding to DNA. Science 1978;199:307-9.

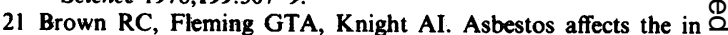
vitro uptake and detoxification of aromatic compounds. Environ Health Perspect 1983;51:315-8.

22 McNeill IM, Wills ED. The formation of mutagenic derivatives $\vec{\circ}$ of benzo(a)pyrene by peroxidising fatty acids. Chem Biol Interact 1985;53:197-207.

\section{Vancouver style}

All manuscripts submitted to the $B r J$ Ind Med should conform to the uniform requirements for manuscripts submitted to biomedical journals (known as the Vancouver style)

The $B r J$ Ind Med, together with many other international biomedical journals, has agreed to accept articles prepared in accordance with the Vancouver style. The style (described in full in $\mathrm{Br}$ Med J, 24 February 1979, $\mathrm{p} \mathrm{532)}$ is intended to standardise requirements for authors.

References should be numbered consecutively in the order in which they are first mentioned in the text by Arabic numerals above the line on each occasion the reference is cited (Manson" confirmed other reports ${ }^{2-5} \ldots$.). In future references to papers submitted to the $\mathrm{Br} J$ Ind Med should include: the names of all authors if there are six or less or, if there are more, the first three followed by et al; the title of journal articles or book chapters; the titles of journals abbreviated according to the style of Index Medicus; and the first and final page numbers of the article or chapter.

Examples of common forms of references are:

1 International Steering Committee of Medical Editors. Uniform requirements for manuscripts submitted to biomedical journals. Br Med J 1979;1:532-5.

2 Soter NA, Wasserman SI, Austen KF. Cold urticaria: release into the circulation of histamine and eosino-phil chemotactic factor of anaphylaxis during cold challenge. $N$ Engl J Med 1976;294:687-90.

${ }^{3}$ Weinstein L, Swartz MN. Pathogenic properties of invading micro-organisms. In: Sodeman WA Jr, Sodeman WA, eds. Pathologic physiology: mechanisms of disease. Philadelphia: W B Saunders, 1974:457-72. 